\title{
МОДЕЛЮВАННЯ МЕТОДИК РЕГІОНАРНОЇ АНЕСТЕЗІЇ ПІД УЛЬТРАЗВУКОВИМ КОНТРОЛЕМ НА ФАНТОМАХ 3 ЗАСТОСУВАННЯМ МЕТОДІВ СТАТИСТИЧНОГО АНАЛІЗУ
}

\author{
Р. В. Бубнов ${ }^{1}$, Л. С. Гнатюк ${ }^{2}$ Ю. С. Синєкоп ${ }^{2}$ \\ Клінічна лікарня "Феофанія" Державного управління справами, центр ультразвукової \\ діагностики та інтервенційної сонографрії \\ Національний технічний університет Украӥни «Київський політехнічний інститут»"
}

В статті порівнюються різні способи введення голки при регіонарній анестезії, що впливають на ультразвукову візуалізацію. Проведено статистико-математичний аналіз отриманих у результаті експерименту даних.

Ключові слова: регіонарна анестезія, сонографічна візуалізація.

\section{МОДЕЛИРОВАНИЕ МЕТОДИК РЕГИОНАРНОЙ АНЕСТЕЗИИ ПОД УЛЬТРАЗВУКОВЫМ КОНТРОЛЕМ НА ФАНТОМАХ С ПРИМЕНЕНИЕМ МЕТОДОВ СТАТИСТИЧЕСКОГО АНАЛИЗА}

\author{
Р. В. Бубнов ${ }^{1}$, Л. С. Гнатюк ${ }^{2}$ Ю. С. Синекоп ${ }^{2}$ \\ Клиническая больница "Феофрания" Государственного управления делами, центр ульт- \\ развуковой диагностики и интервенционной сонографрии ${ }^{1}$ \\ Национальный Технической Университет Украины «Киевский Политехнический Институт»² \\ В статье сравниваются разные способы введения иглы при региональной анестезии, влияющие на ультразвуко- \\ вую визуализацию. Проведен статистико-математический анализ полученных в результате эксперимента данных. \\ Ключевые слова: регионарная анестезия, сонографическая визуализация.

\section{PHANTOM MODELING OF REGIONAL ANASTHESIA UNDER ULTRASOUND GUIDANCE USING METHODS OF STATISTICAL ANALYSIS} \\ R. V. Bubnov ${ }^{1}$, L. S. Hnatiuk ${ }^{2}$, Yu. S. Synekop ${ }^{2}$ \\ Clinical Hospital "Pheophania" of State Affairs Department,the Center of Ultrasound \\ Diagnostics and Interventional Sonography ${ }^{1}$, \\ National Technical University of Ukraine "Kyiv Polytechnic Institute"2
}

The paper compares different techniques of needle insertion during phantom modeling of regional anesthesia affecting ultrasound visualization. A statistical analysis of experimental data for methodics optimization was conducted.

Key words: regional anesthesia, sonographic visualization, phantom, needle.

Вступ. Проведення ультразвукового (Уз) контролю реііонарної анестезії вимагає постійного вдосконалення мультидисциплінарного підходу з аналізом помилок і розробкою диференційованого підходу до кожної клінічної ситуації з доведенням ефективності блокади до 100 \%. В клінічній лікарні «Феофанія» виконують у повному обсязі увесь спектр сучасних блокад різних локалізацій. Розроблено критерії сонографічної візуалізації нервів та окремі суперселективні ме- тодики реііонарної анестезії й принципи оптимізації методики блокади [1]. Ультразвукова візуалізація голки при виконанні регіонарної анестезії є важливим компонентом для забезпечення безпеки і успіху маніпуляції. Голка візуалізується у вигляді гіперехогенної структури з тотальною дистальною акустичною тінню. Точність ідентифікації голки робить мінімальним пошкодження довколишніх тканин та оптимізує введення анестезувального засобу. Попередні дослідження 
в репонарши анестезії вивчали видимість різних голок, деякі з яких були спеціально змінені для поліпшення ехогенності [2-6]. Повідомлено про використання п'єзоелектричного приводу для покращення візуалізації голки за допомогою кольорового Допплера [7]. Ці спеціально виготовлені голки мають підвищені властивості відбиття ультразвукових променів на межі голки та тканин за рахунок спеціального стилету 3 п'єзоелектричним кристалом, зв'язаним з УЗ-апаратом. Кристал посилає сигнал у вигляді червоної крапки на екрані. Проте якість візуалізації голки та ії кінчика була оцінена переважно на основі суб' єктивних оцінок дослідників, хоча одне дослідження з вивчення регіональної анестезії описує об' єктивні показники яскравості голки з допомогою розрахунку інтенсивності пікселів [8]. Наш досвід свідчить, що немає спеціальних властивостеи голок, що суттєво покращують їх візуалізацію при сонографії. Проте спосіб введення голки, ïi положення, переміщення та їх кут відносно датчика визначають якість візуалізації. Тому оптимізація умов проведення пункції під УЗ-контролем приводить до кращої візуалізації голки.
При проведенні реііонарної анестезії під ультразвуковим контролем, крім засвоєння соноанатомії регіонарної анестезії, оператор повинен відпрацювати дві основні практичні навички: (а) можливість узгодження голки для ультразвукового променя, а також (б) правильно визначати доступ за умови постійної візуалізації голки. При виконанні блоків слід завжди утримувати у полі зору голку на всій довжині та обов 'язково ідентифікувати ії кінчик та просувати його під УЗконтролем. Такі навички можна набути при виконанні пункцій на спеціально створених фантомах для інтервенційного ультразвуку, пристосованих для реііонарної анестезії. Навчання на фантомах є першим кроком навчальних програм для засвоєння методик інтервенційного ультразвуку. Нами розроблено спеціальні фантоми [9] для навчання інтервенційних методик під УЗ контролем (рис. 1), в тому числі регіонарної анестезії під контролем УЗД, де точне диференціювання тубулярних структур є основою методу. Розроблені власні фантоми є ефективними як на початкових етапах оволодіння методикою, так і для експертів, у тому числі для дослідницьких робіт [10].

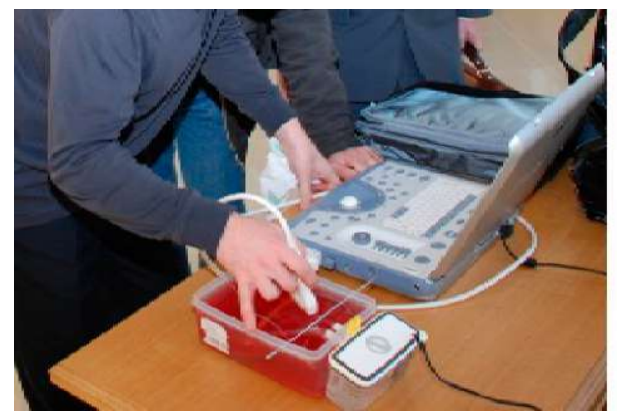

$\mathbf{a}$

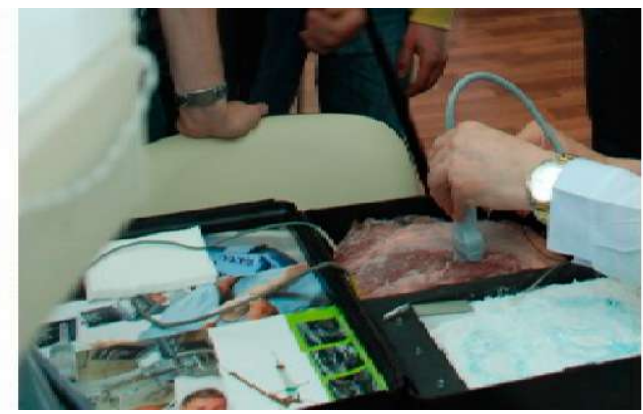

б

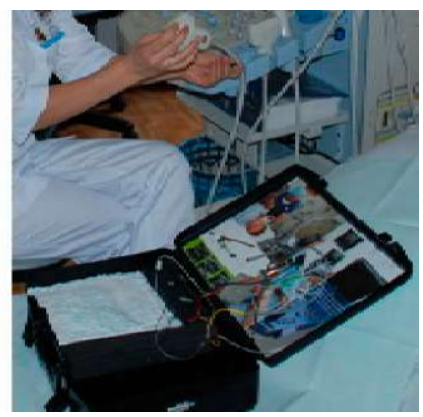

B

Puc. 1. Фантом, який використовується в якості навчального муляжу на ранніх етапах навчання (а - гелевий фантом, б - фантом біологічної тканини (м'ясо), в - механічно-електронний тренажер для РА).

Метою дослідження було порівняння різних способів введення голки, що впливають на їі ультразвукову візуалізацію при моделюванні регіонарної анестезії на фантомах.

Матеріали дослідження. Згідно 3 поставленою метою в дослідження включили дві групи лікарів - 5 лікарів-анестезіологів, які не мали попереднього досвіду в інтервенційному ультразвуку та групу з 5 чоловік- експертів (лікарів з УЗД) з попереднім досвідом пункційних втручань під УЗ-контролем.

У3 обстеження проводили за допомогою портативного ультразвукового апарату Sonosite M-Turbo 3 використанням мультичастотних лінійного (8-12 МГц) та конвексного датчиків (3-5 МГц) та апарату Hitachi HV900. Дослідження проводили на власних фантомaх, що включали гелевий фантом, біологічний фан- том та електроннии пристріи для реєстрації точного потрапляння голки в об'єкт.

Усі спеціалісти - лікарі з УЗД (експерти) та лікарі-анестезіологи (новачки) виконали по 30 пункціИ для групи кожного з досліджень. Були виключені принципові відмінності між кваліфікацією операторів-неспеціалістів, усі лікарі з УЗД мали досвід інтервенційної сонографії, експерименти були проведені у відносній ізоляції. Наше дослідження проводилося 3 використанням як фантома на основі тканини тварин, так і гелево-водяних фантомів, що може вплинути сонографічне відображення голки. Проводилось об'єктивне нотування ефекту пункційного випробовування за допомогою електронного пристрою для реєстрації точного потрапляння голки в об'єкт. 
Оброблення експериментальних даних. Для оброблення отриманих даних використовували середовище МЛТьЛБ.

Порівнюючи 2 групи лікарів (новачків та експертів), визначали вплив методу введення голки на ефективність пункції. Для прийняття рішення про те, чи впливає метод введення голки на результат пункції, використовували статичні критерії. В даному випадку визначали критерій Стьюдента (Іжритерій). Отримане значення критерію порівнювали 3 відомим еталонним числом, що називається критичним значенням критерію [11].

Для довірчої ймовірності 95 \%, теоретичне значення критерію Стьюдента $\digamma_{\text {meор }}=2,2281$ менше за обидва отримані значення критерію Стьюдента $r=7,61$ та $r=5,8$ (лікарі-новачки на гелевому та біологічному фантомах відповідно). 3 цього робимо висновок, що вплив методу введення голки на попадання в ціль доведено.

Порівнюючи теоретичне значення критерію Стьюдента 3 отриманим значенням (біологічний фантом) $t_{\text {meop }}=2,2281<t=2,925, \quad$ та $t_{\text {meop }}=2,2281>t=1,94$ (гелевий фантом), можна зробити висновок, що метод введення голки впли- ває на ефективність пункції тільки на біологічному фантомі.

Для даних експерименту, які наведено в таблиці 3, проведено регресійний аналіз. Його мета - знайти функціональну залежність між змінними. Вважається, що залежна змінна визначається відомою функцією, яка залежить від залежної змінної або змінних, та деякого параметра. Потрібно знайти такі значення цього параметра, щоб отримана залежність (модель) найкращим чином описувала наявні експериментальні дані.

Встановимо зв'язок між однією незалежною змінною х (кут введення голки) та залежною змінною $y$ (кількість попадань в ціль). Вважається, що незалежна змінна $x$ неперервна та може контролюватись експериментатором, тобто кут введення голки може змінювати експериментатор, та спостерігати певні значення $y$ - попадання або не попадання в ціль.

На рисунках 9 та 10 зображено експериментальні точки та відповідні точки, які отримані за моделлю. Для новачків похибка при описанні даних експерименту регресійною моделлю становить 0,015 - на гелевому фантомі та 0,0068 - на біологічному, а для експертів - 0,042.

Результати. Всі лікарі пройшли інтервенційні випробування. Результати порівняльного дослідження проведення пункцій за різними способами представлені у таблицях 1-3 та на рисунках 2-10.

Таблиця 1. Порівняльне дослідження проведення пункції за допомогою насадки та методом «вільної руки»

\begin{tabular}{|c|c|c|}
\hline Група лікарів & Пункція за допомогою насадки & Пункція методом «вільної руки» \\
\hline \multicolumn{3}{|c|}{ На гелевому фантомі } \\
\hline Експерти(п=5) & $4,8(96,6 \%)$ & $4,5(90 \%)$ \\
\hline Новачки $(\Pi=5)$ & $4,3(86,6 \%)$ & $2,7(53,3 \%)$ \\
\hline \multicolumn{3}{|c|}{ На біологічному (м'ясному) фантомі } \\
\hline Експерти(п=5) & $3,8(76,7 \%)$ & $4,7(93,3 \%)$ \\
\hline Новачки $(\Pi=5)$ & $1,6(33,3 \%)$ & $3,5(70 \%)$ \\
\hline
\end{tabular}

Таблиця 2. Порівняльне дослідження помилки при пункції об' єкта на різній глибині

\begin{tabular}{|l|c|c|c|}
\hline \multirow{2}{*}{ Групи дослідників } & \multicolumn{3}{|c|}{ Відсоток ефективності при пункції на глибині } \\
\cline { 2 - 4 } & $2,5 \mathrm{~cm}$ & $4 \mathrm{~cm}$ & $6 \mathrm{~cm}$ \\
\hline Експерти(п=5) & $4,5(90 \%)$ & $4,2(83,3 \%)$ & $4(80 \%)$ \\
\hline Новачки $(п=5)$ & $2,8(56,7 \%)$ & $2,3(46,6 \%)$ & $1,3(26 \%)$ \\
\hline
\end{tabular}

Таблиця 3. Порівняльне дослідження ефективності пункції в повздовжньому скануванні під різним кутом введення голки

\begin{tabular}{|l|c|c|c|c|}
\hline \multirow{2}{*}{ Кут введення } & \multicolumn{2}{|c|}{ На гелевому фантомі } & \multicolumn{2}{|c|}{ На біологічному фантомі } \\
\cline { 2 - 4 } & експерти & новачки & експерти & новачки \\
\hline $15-25^{\circ}$ & $4,5(90 \%)$ & $4(80 \%)$ & $4,2(83,3 \%)$ & $3,3(66,6 \%)$ \\
\hline $35-45^{\circ}$ & $4,5(90 \%)$ & $3,5(70 \%)$ & $3,7(73,3 \%)$ & $2,8(56,6 \%)$ \\
\hline $55-65^{\circ}$ & $4(80 \%)$ & $3,3(66 \%)$ & $3,7(73,3 \%)$ & $2,5(50 \%)$ \\
\hline
\end{tabular}


На рисунках 2 та 3 представлено діаграми, що ілюструють дані таблиці 1. 3 діаграм видно, що виконання пункції на гелевих фантомах з однорідним за фізичними показниками середовищем для обох груп

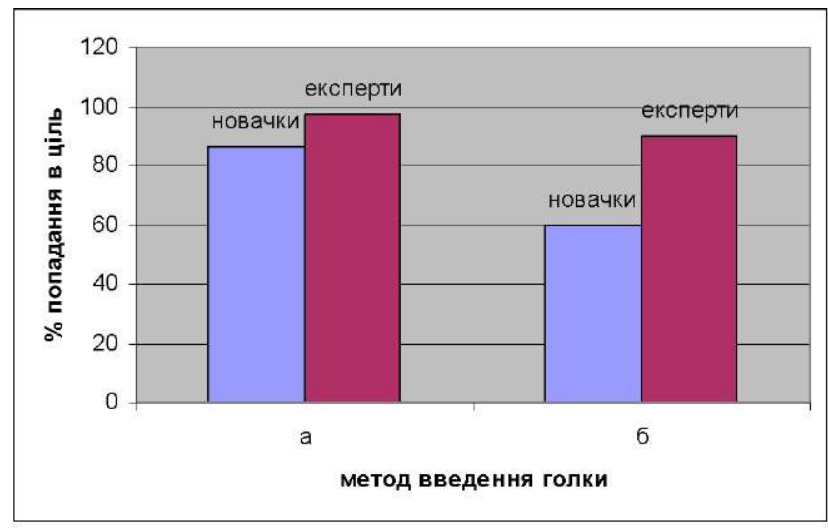

Puc. 2. Ефективність пункції за допомогою насадки (а) та методом «вільної руки» на гелевому фантомі.

Проте на біологічному (м'ясному) фантомі, який моделює умови пункції під час регіонарної анестезії в клінічних умовах, виконання пункції ефективніше за методом «вільної руки» для обох груп.

В таблиці 2 наведені результати наступного експерименту - дослідження впливу глибини залягання об'єкта на ефективність пункції. Як видно з таблиці 2 та рисунків 4, 5, експерти ефективніше виконують пункцію на різній глибині, ніж новачки, причому успішність знижується при збільшенні глибини залягання для обох груп. Однак у представників групи експертів різниця на глибині 4 см та 6 см незначна, а новачки ефективніше потрапляють в менш глибоко розташований об'єкт (2,5 см). Як видно з рисунка 5, ефективність у новачків різко знижується зі збільшенням глибини залягання об'єкта.

В таблиці 3 представлено дані третього експерименту - дослідження залежності ефективності пункції

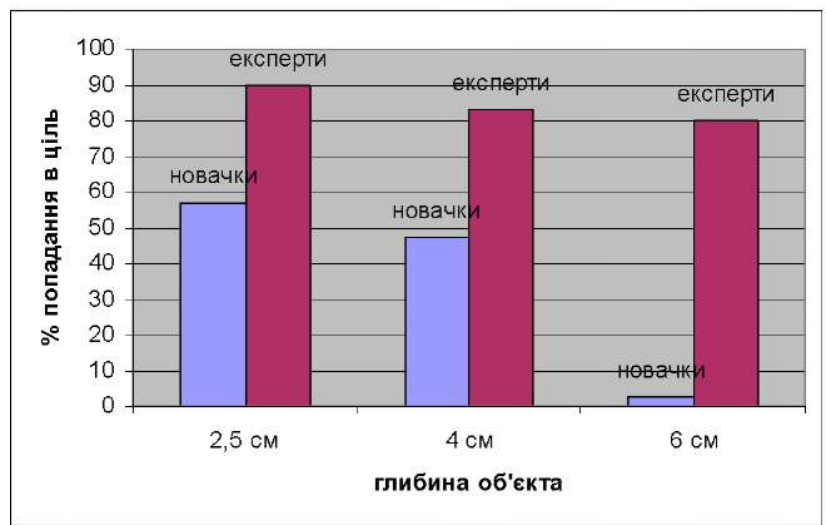

Puc. 4. Ефективність пункції на різній глибині об'єкта. ефективніше з використанням спеціального пристрою - насадки для керування уколу голки. Причому експерти з поставленою задачею справились краще, ніж лікарі без попереднього досвіду.

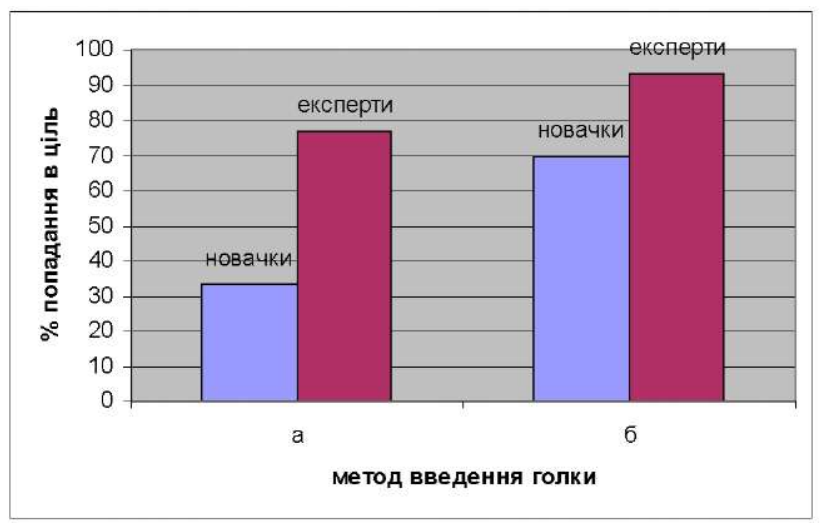

Puc. 3. Ефективність пункції з допомогою насадки

(a) та методом «вільної руки» на біологічному фантомі.

від кута введення голки. 3 результатів видно, що вищою була ефективність пункції при менших кутах введення голки для обох груп на обох видах фантомів та зменшувалась в міру збільшення кута введення голки.

Обговорення. Проведення регіональної анестезії під УЗ контролем в майбутньому стане стандартним методом лікування, але для цього потрібно вирішити ряд деяких завдань: розробка ряду керівних принципів для вирішення навчальних програм і сфе-

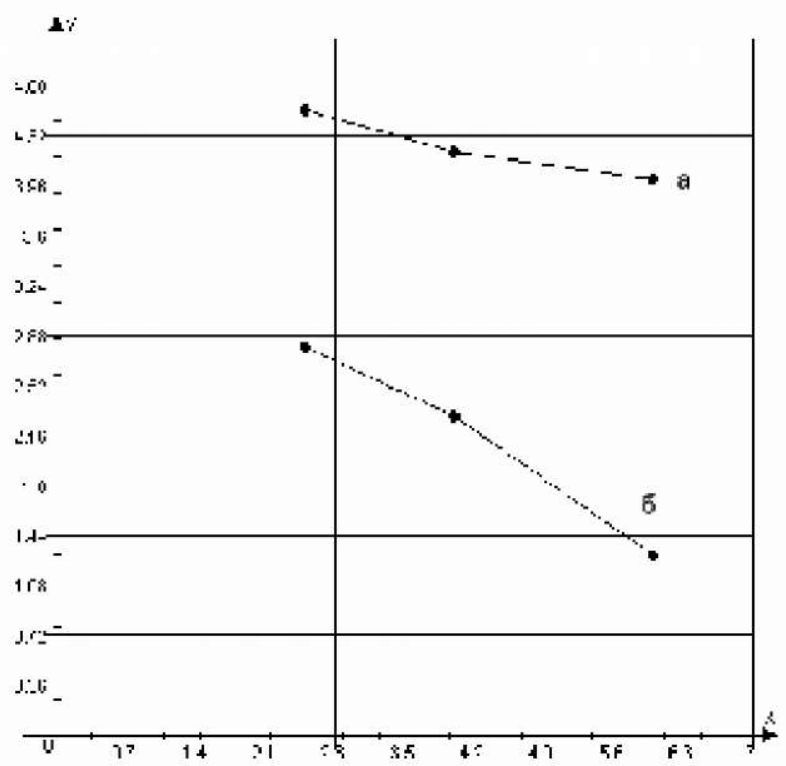

Puc. 5. Порівняльний графік залежності ефективності пункції, тобто попадання в ціль (вісь у) від глибини залягання досліджуваного об'єкта (вісь х); a - експерти, б - новачки. 


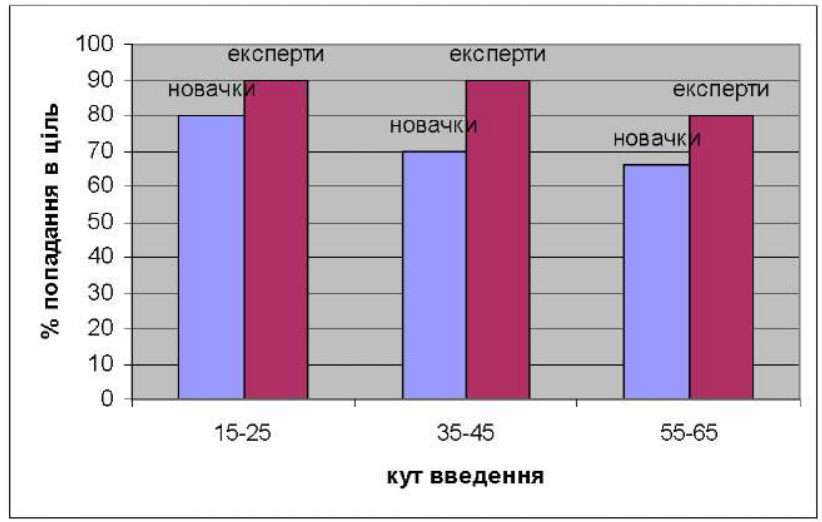

Puc. 6. Ефективність пункції під різним кутом введення голки на гелевому фантомі.

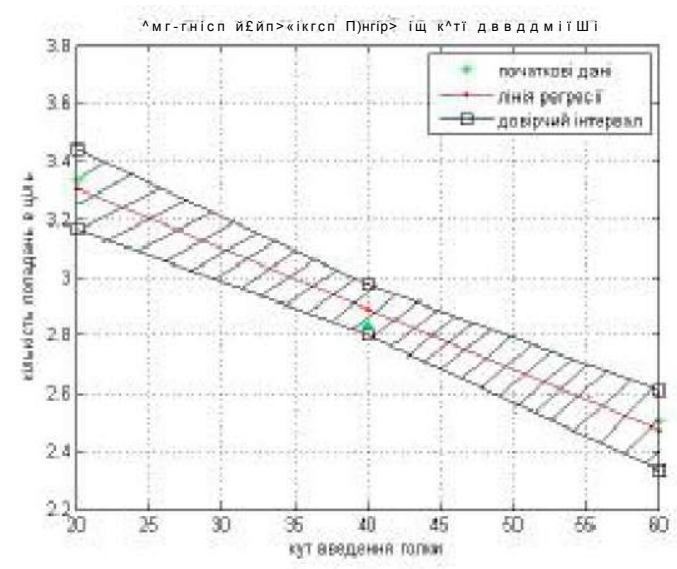

a)

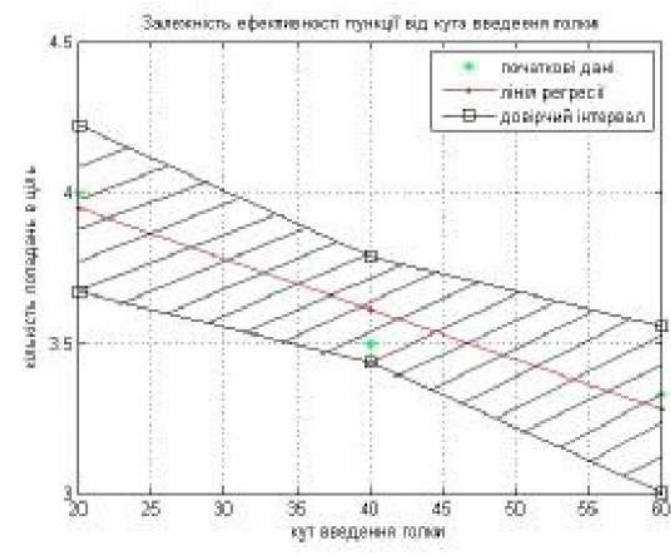

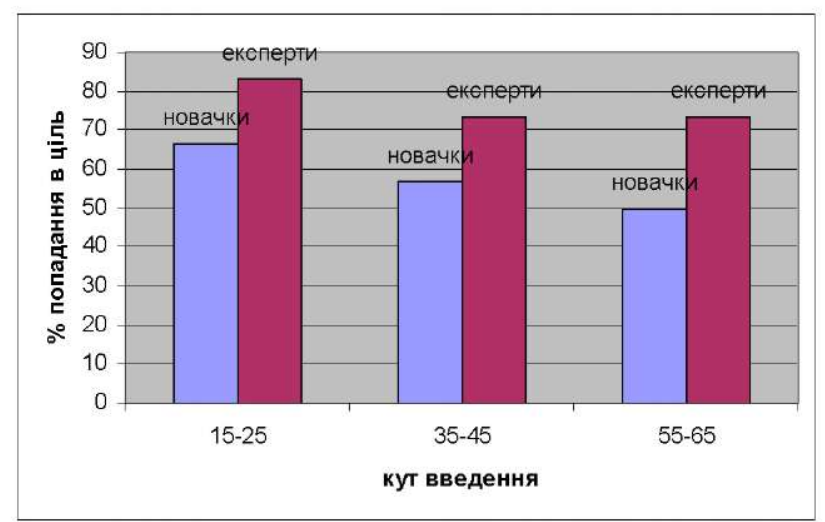

Puc. 7. Ефективність пункції під різним кутом введення голки на біологічному фантомі.

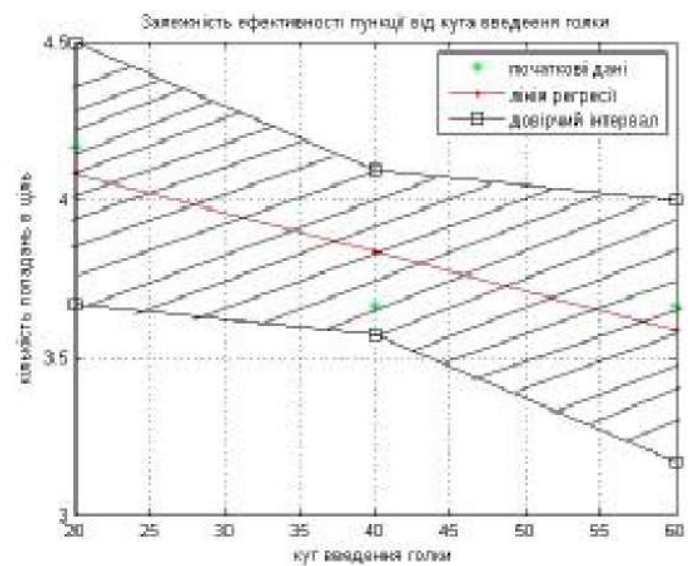

б)

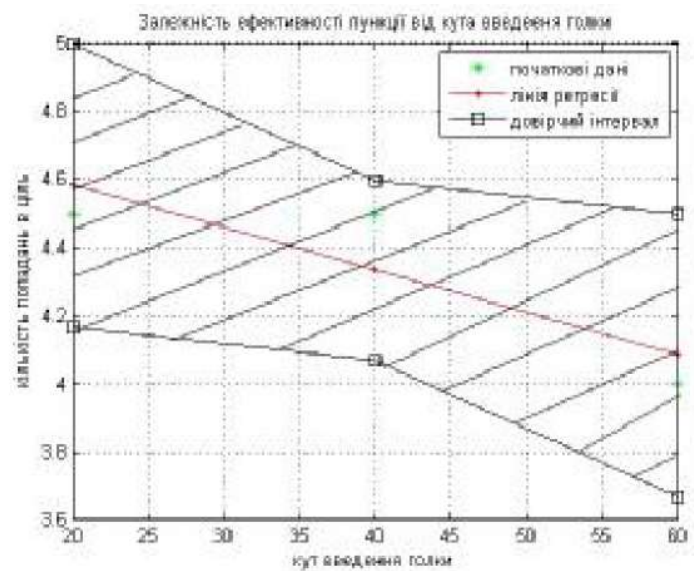

B)

Puc. 8. Графічна інтерпретація довірчого інтервалу.

а, в - новачки на біологічному та гелевому фантомах відповідно; б, г - експерти на біологічному та гелевому фантомах відповідно.

ри практичного застосування РАУЗ, подальше вдосконалення технології УЗД, необхідного для підвищення візуалізації дрібних нервів, наприклад бічного шкірного нерва стегна, глибоко розташованих нервів. Проблемою залишається візуалізація голки, тому слід сподіватися на подальший розвиток ії сонографічних властивостей.
В результаті проведених експериментів можна відзначити, що на ефективність пункції впливають такі фактори:

- метод введення голки;

- глибина залягання біологічного об'єкта (нерва);

- кут нахилу введення голки;

- професійні навички лікарів. 


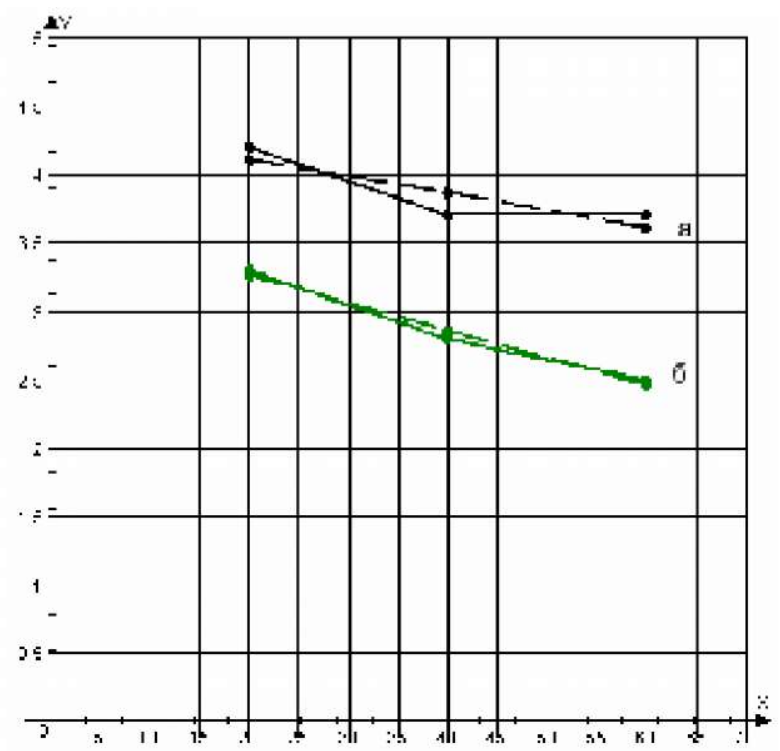

Puc 9. Експериментальні точки та відповідні значення, які отримані за моделлю; біологічний фантом (а - експерти, б - новачки).

При введенні голки із використанням спеціального пристрою - насадки для керування уколом голки кількість ефективно проведених пункцій $є$ вищою, ніж при введенні методом «вільної» руки.

Зі збільшенням глибини залягання об'єкта відсоток попадань в ціль зменшується як у лікарів з попереднім досвідом пункційних втручань, так і в лікарів-анестезіологів без попереднього досвіду в інтервенційному УЗ. Такий результат можна пояснити тим, що зі збільшенням глибини важче ідентифікувати ціль влучення, тобто роздільна здатність з глибиною погіршується.

Ефективність пункції погіршується зі збільшенням кута введення голки. Найкращі результати пункції були при куті нахилу голки на $15^{\circ}-20^{\circ}: 86,65 \%$ влучень в ціль у експертів, та 73,3 \% - в новачків. Гірші резуль-

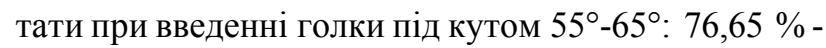
експерти та 58 \% - новачки.

Проте, хоча видимість голки за допомогою ультразвуку при ії введенні під великим кутом залишається проблематичною, таке введення, як і раніше, необхідне, особливо у пацієнтів з ожирінням, при деяких видах блокад, як наприклад, нейроаксіальні методики анестезії чи паравертебральні ін'єкції. В таких випадках при виконанні пункції в поперечному скануванні доцільно використовувати метод "walk-down" ("просування вниз") для доступу в поперечному скануванні і для визначення глибини локалізації цільової структури. Місце проколу вибирають для досягнення однакової відстані, з цільовою глибиною, яку встановлено сонографічно. Голку вводять під невеликим кутом для візуалізації iї кінчика. Голку поступово відстежують

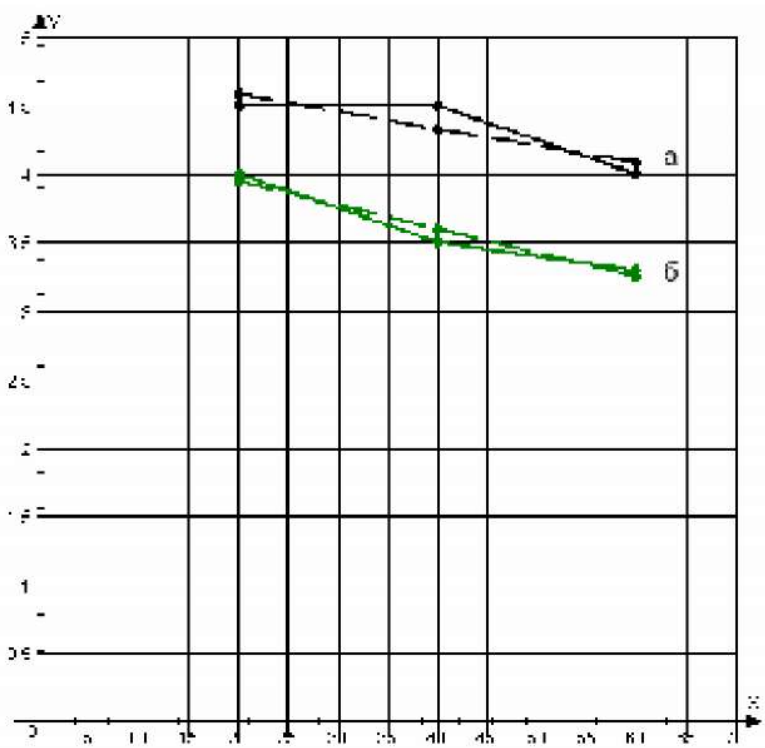

Puc. 10. Експериментальні точки та відповідні значення, які отримані за моделлю; гелевий фантом (а - експерти, б - новачки).

під гострим кутом до досягнення кута приблизно $45^{\circ}$. Геометрично при введенні голки під кутом $45^{\circ}$, ультразвуковий датчик та шкіра утворюють рівнобедрений прямокутний трикутник з глибиною, рівною відстані від датчика. Допоміжні прийоми, наприклад рухи голки, можуть допомогти в таких ситуаціях (рис. 11).

Також важливе значення має попередній досвід лікарів. У всіх експериментах лікарі УЗД показали

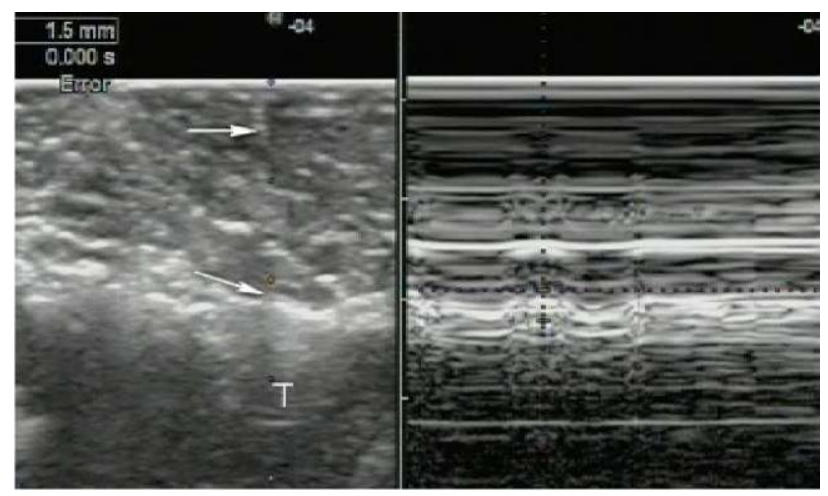

Puc. 11. Допоміжний прийом візуалізації кінчика голки - оцінка руху щільних тканин (фасції) при проколюванні їх голкою в поперечному скануванні.

кращі результати (85,08 \% попадань в ціль), ніж лікаріанестезіологи (56,26\%).

Слід зазначити, що виконання пункції на гелевих фантомах з однорідним за фізичними показниками середовищем для обох груп ефективніше, оскільки роздільна здатність зображення однорідного середовища вища, ніж неоднорідних структур, в даному випадку м'яса (рис. 12). 


\section{МЕДИЧНА ІНФОРМАТИКА ТА ІНЖЕНЕРІЯ}
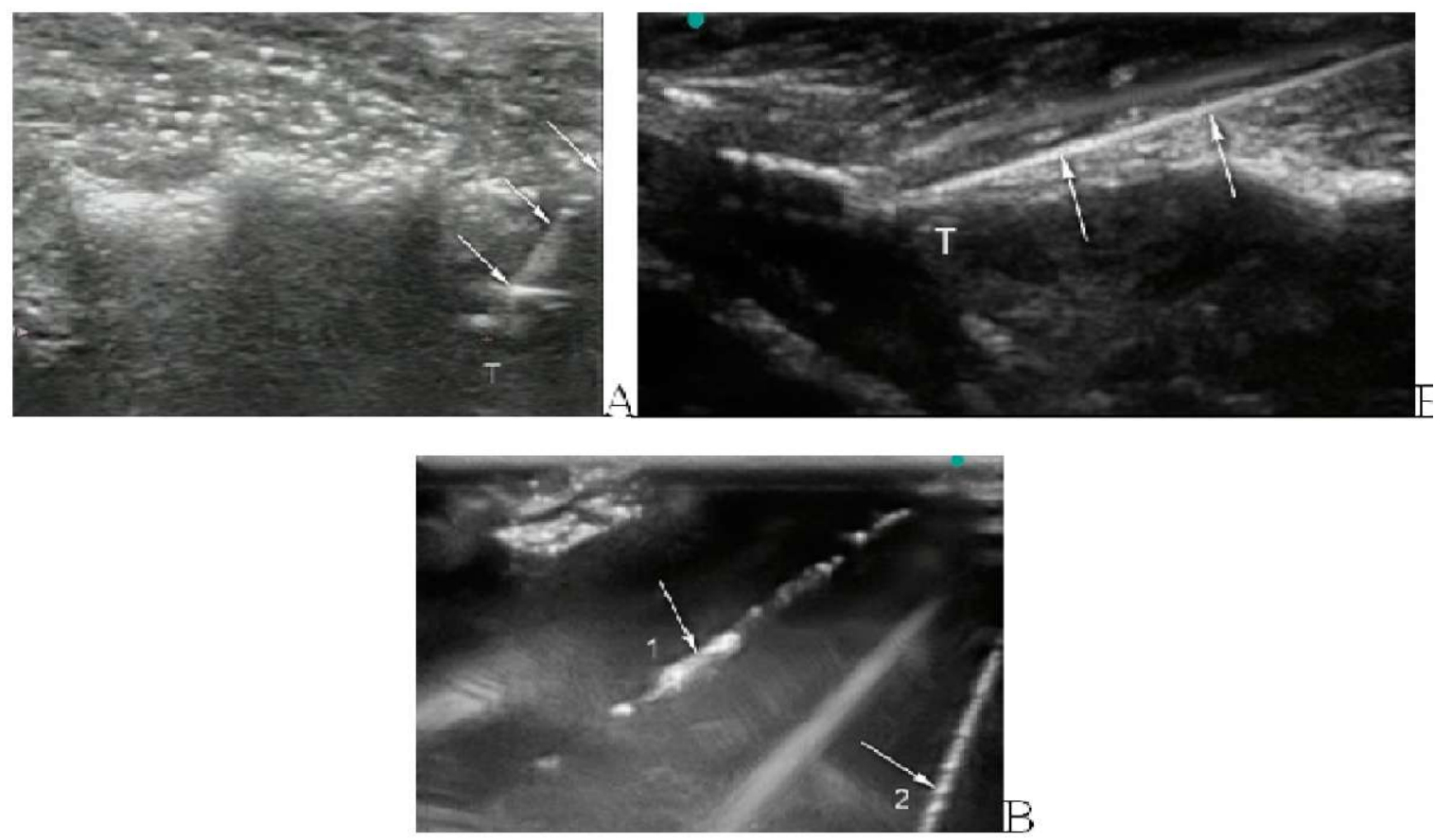

Puc. 12. Якість візуалізації голки в поздовжньому скануванні А - на м'ясному фантомі при великому куті введення голки; Б - на м'ясному фантомі при малому куті введення голки; В - при малому (1) та великому (2) куті введення голки на гелевому фантомі.

Висновки. Лікарі анестезіологи, без попереднього досвіду в ультразвуковій діагностиці, здатні опанувати основи виконання інтервенційних маніпуляцій під УЗконтролем у модельованій ситуації $з$ використанням фантомів. Проте показники якості виконання маніпуляції нижчі, ніж у фахівців з інтервенційної сонографії.

Спосіб введення голки, її положення, переміщення та iï кут відносно датчика суттєво впливають на

\section{Література}

1. Бубнов Р. В. Ультразвуковой контроль проведения регионарной анестезии при операциях на нижних конечностях / Р. В. Бубнов // Международный медицинский журнал. 2010. -№>1. - C. 99-103.

2. Edgcombe H. Sonographic identification of needle tip by specialists and novices: a blinded comparison of 5 regional block needles in fresh human cadavers / H. Edgcombe, G. Hocking// Reg. Anesth. Pain Med. - 2010. - P. 207-211.

3. Needle visualization in ultrasound-guided regional anesthesia: challenges and solutions / K. J. Chin, A. Perlas, V W. Chan, R. Brull// Reg. Anesth. Pain Med. - 2008. - P. 532-544.

4. Chapman G. A. Visualisation of needle position using ultrasonography / G. A. Chapman, D. Johnson, A. R. Bodenham // Anaesthesia. - 2006. - P. 148-158.

5. Schafhalter-Zoppoth I. Ultrasound visibility of needles used for regional nerve block: an in vitro study / I. SchafhalterZoppoth, C. E. McCulloch, A. T. Gray // Reg. Anesth. Pain. Med. - 2004. - P. 480-488.

6. Maecken T. Ultrasound characteristics of needles for regional якість візуалізації. Тому оптимізація умов проведення пункції під УЗ-контролем приводить до кращої візуалізації голки. Результати досліджень можуть бути основою обгрунтування методології проведення регіонарної анестезії під УЗ-контролем для запобігання ятрогенним ушкодженням в реальних ситуаціях, а також слугувати створенню навчальних програм РАУЗ.

anesthesia/ T. Maecken, M. Zenz, T. Grau// Reg. Anesth. Pain Med. - 2007. - P. 440-447.

7. Piezoelectric vibrating needle and catheter for enhancing ultrasound-guided peripheral nerve blocks / S. M. Klein, M. P. Fronheiser, J. Reach [et al.] //Anesth. Analg. -2007. - P 58-60. 8. Ultrasound visibility of needles used for regional nerve block: an in vitro study / I. Schafhalter-Zoppoth, C. E. McCulloch, A. T. Gray // Reg. Anesth. Pain. Med. - 2004. P. 480-488.

9. Патент 794667 Україна. Спосіб створення фантомів для моделювання регіонарної анестезії під ультразвуковим контролем / Бубнов Р. В., Мухомор О. І., Строкань А. М. № u201103447; опубл. 23.03.2011.

10. Синекоп Ю. С. Экспериментальное определение основных характеристик ультразвуковых преобразователей / Ю. С. Синекоп, А. И. Мухомор, Р. В. Бубнов // Электроника и связь . - 2010.- №> 5. - С. 154-159.

11. Біометрія / Ю. С. Синєкоп, О. П. Мінцер, К. В. Ружицька, В. Б. Мілій. - К. : НВФ «March-А», 2008. - 138 с. 